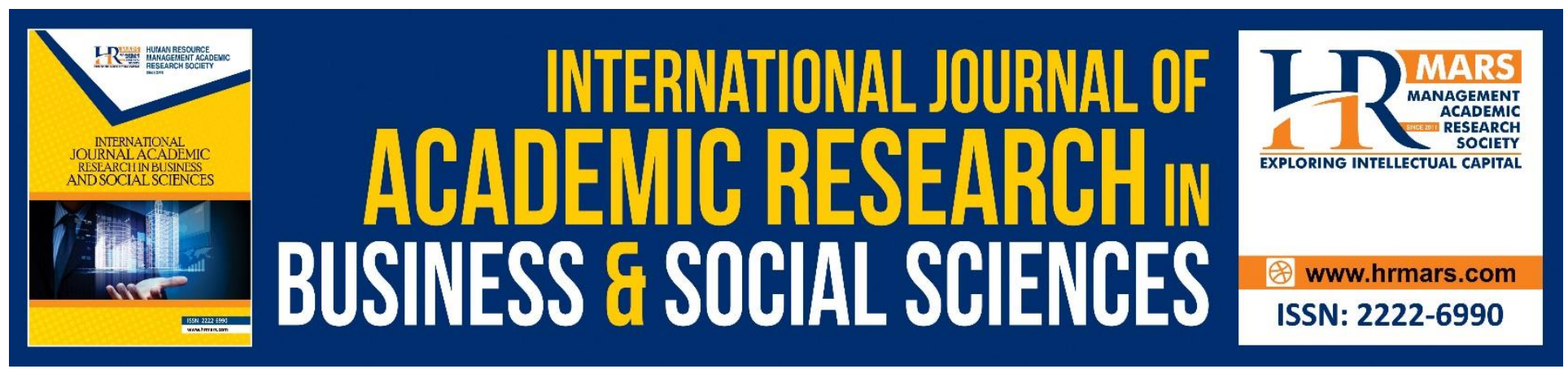

\title{
Reputation, Competitive Advantage and Financial Performance of Infaq Received Among Private Islamic Schools in Malaysia
}

Azira Hanani Ab Rahman, Sofri Yahya

To Link this Article: http://dx.doi.org/10.6007/IJARBSS/v10-i9/7868

DOI:10.6007/IJARBSS/v10-i9/7868

Received: 27 June 2020, Revised: 23 July 2020, Accepted: 16 August 2020

Published Online: 07 September 2020

In-Text Citation: (Ab Rahman, \& Yahya, 2020)

To Cite this Article: Ab Rahman, A. H., \& Yahya, S. (2020). Reputation, Competitive Advantage and Financial Performance of Infaq Received Among Private Islamic Schools in Malaysia. International Journal of Academic Research in Business and Social Sciences. 10(9), 798-808.

\section{Copyright: (C) 2020 The Author(s)}

Published by Human Resource Management Academic Research Society (www.hrmars.com)

This article is published under the Creative Commons Attribution (CC BY 4.0) license. Anyone may reproduce, distribute, translate and create derivative works of this article (for both commercial and non-commercial purposes), subject to full attribution to the original publication and authors. The full terms of this license may be seen

at: http://creativecommons.org/licences/by/4.0/legalcode

\section{Vol. 10, No. 9, 2020, Pg. 798 - 808}

Full Terms \& Conditions of access and use can be found at http://hrmars.com/index.php/pages/detail/publication-ethics 


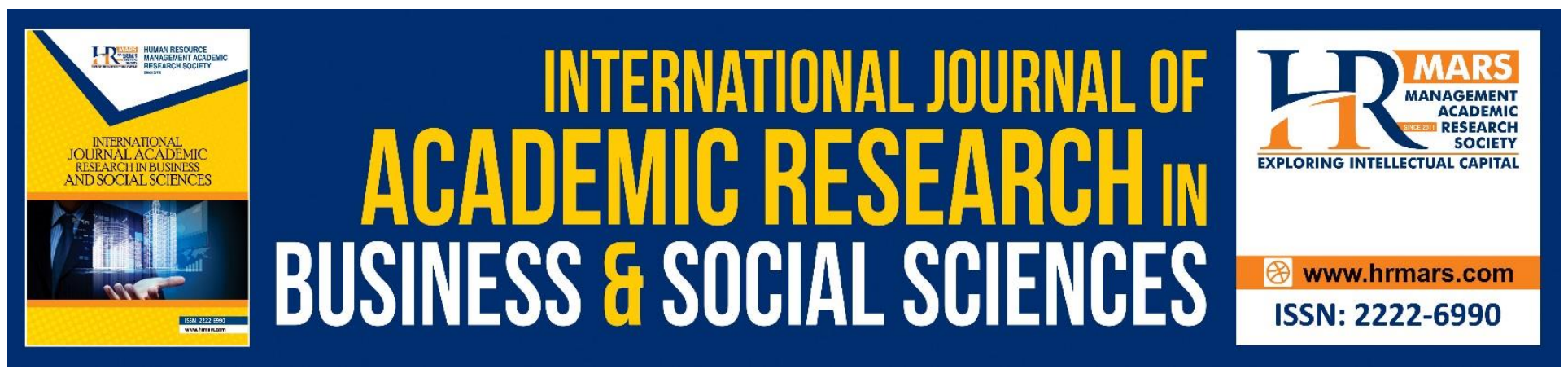

\title{
Reputation, Competitive Advantage and Financial Performance of Infaq Received Among Private Islamic Schools in Malaysia
}

\author{
Azira Hanani Ab Rahman, Sofri Yahya \\ Graduate School of Business, Jalan Ilmu, Universiti Sains Malaysia, 11800 Pulau Pinang
}

\begin{abstract}
To sustain a competitive advantage, organisations should procure resources and use it towards this objective, which would ultimately lead to superior performance. Academics and business professionals consider the most valuable resources of an organisation are good reputation. Performance of infaq receive by private Islamic schools is closely related to the donating behaviour of the donors. In today's highly competitive and resource-scarce environment, the private Islamic schools as non-profit organisations must create a positive image and reputation to gain the public's favour and trust and consequently, more donations. As the number of private Islamic schools increased yearly, each school needs to identify its competitive advantage in order to be more attractive in the eye of the stakeholders. Using a cross sectional survey design, this study intended to explore the relationship of reputation and competitive advantage to the financial performance of infaq received by private Islamic schools in Malaysia. The SmartPLS (v. 3.2.9) software was used to run the Structural Equation Modelling (SEM) technique and the findings showed that the competitive advantage is influenced by reputation, however the competitive advantage does not lead to superior performance of infaq received by private Islamic schools in Malaysia. It is hoped that future studies focus on separate studies involving pondok institution, tahfiz schools as well as SRI and SMI to obtain more comprehensive results.
\end{abstract}

Keywords: Reputation, Competitive Advantage, Performance, Donation, Private Islamic Schools.

\section{Introduction}

Non-profit organisations generally receive contributions from the general public, corporations or other stakeholders. Donations from various stakeholders are an important source of funding since these organisations depend on it to run their organisations and carry out their responsibilities. As a non-profit organisation, most private Islamic schools in Malaysia depend on public donations to finance their operations since students' fees alone are not enough to cover operating and development costs. The financial performance of infaq received by private Islamic schools is closely related to the giving behaviour of donors and other stakeholders. In today's highly competitive and resource-scarce environment, non-profit organisations must create a positive image and reputation 
INTERNATIONAL JOURNAL OF ACADEMIC RESEARCH IN BUSINESS AND SOCIAL SCIENCES Vol. 10, No. 9, 2020, E-ISSN: 2222-6990 @ 2020 HRMARS

to gain the public's favour and trust and consequently, more donations, since the image and reputation of these organisations is critical to influence a donor's behaviour (Huang \& Ku, 2016). However, the growing number of negative issues faced by private Islamic schools in Malaysia, as reported in the local media, might have tarnished the reputation of these schools. This situation has raised public concern over the operation and existence of these schools (Andres, 2017; Aziz, 2018; Bernama, 2018; Ying, 2018). Furthermore, as the number of private Islamic schools increased yearly (Ambotang \& Majuleka, 2018; Ibrahim et al., 2005; Ismail, 2016), this situation had forced schools to compete with other schools for the pool of resources. In order to survive the competition, each school needs to identify its competitive advantage and perform better than other schools. Each school must have the capability to attain and sustain its advantage over its competitors in order to be more attractive in the eye of the stakeholders.

Therefore, to establish a good reputation is the key concern of the private Islamic school's management is in order to attract more students to study at their institution as well as to gain the support of potential donors. Good reputation could pave the way for these private Islamic schools to be competitive in the market, which could then influence stakeholders to consistently contribute funds to these schools. Thus, this study attempts to unravel the issue by exploring the relationship between reputation, competitive advantage and the financial performance of infaq received by private Islamic schools in Malaysia.

The study consists of four parts. Firstly, this study discuss on the overview of reputation and competitive advantage. Secondly the literature review and past studies related to reputation, competitive advantage and financial performance, as well as the research framework and hypothesis will be described and explained. Thirdly, the method of the study is presented. Finally, the results of the study are presented, analysed and discussed, followed by conclusion including managerial implications concerning reputation will be provided.

\section{Literature Review \\ Financial Performance}

Roberts and Dowling (2002) posited that organisations with priceless, rare, and inimitable assets like a good reputation and competitive advantage can attain a sustained superior financial performance. Reputation is of immense significance as it increases an entity's value, which hampers other competitors from competing with these entities and their values. Financial performance can be measured by using several means. Numerous studies have adopted subjective approaches to measure financial performance for several reasons. According to Man (2011), as quoted by Agyemang and Ansong (2017), another method for evaluating an organisation's financial performance is to use scales instead of using actual figures as the reluctance to divulge confidential facts and figures is prevalent among some owner/managers. Generally, managers will be unwilling to reveal the actual performance data if it is considered commercially sensitive or confidential. Due to the public unavailability of financial information regarding private Islamic schools and the possibility of school managers unwilling to disclose sensitive information, hence, this study adopted the subjective approach of measuring financial performance and adapting the measurement used by Suomi (2015), which looks at the sufficiency of funds received. 


\section{Competitive Advantage}

Generally, competitive advantage is viewed as how organisations can perform better than their competitors in the same industry. Competitive advantage is a factor for a long-term success and a determinant of survival and development. Barney (1991) highlighted that when an organisation possessed several unique resources and capabilities which competitors find unmatchable then it is called competitive advantage. Non-profit organisations are often competing for a small pool of resources comprising the same money, volunteers, and sometimes the same grants. A good reputation is, by definition, a strategic resource as it exhibits the competitive status of the organisation compared to its rivals. An organisation with favourable organisational reputation has a competitive edge over its rivals (Carmeli \& Tishler, 2005). In a private Islamic school setting, competitiveness of these schools as a non-profit organisation is described as achieving and maintaining an advantage over other schools where they are given the opportunity to display a comparatively competitive model to the industry. This allows the element of competitiveness to be evaluated and assessed by the pertinent parties through determining factors of their competitive advantage. Competitive advantage aims to shine in the eyes of stakeholders compared to other organisations in the same industry. When a particular private Islamic school gains a competitive advantage, it means that the school has something that others do not have, and it perform better than others or does something that the other schools cannot do.

\section{Reputation}

Reputation refers to the perception of stakeholders regarding the capacity of an organisation to create value relative to their rivals (Rindova et al., 2005). Hall (1993) suggested that reputation is a critical source of competitive advantage where organisation's management should pay serious attention to this sensitive resource. Some of the characteristics of reputation are that it is built over time, money cannot buy it and it can be easily damaged. A positive or good reputation bestows firms with innumerable benefits, but the most important would be overwhelming long-term profits (Roberts \& Dowling, 2002). For non-profit organisations, reputation is crucial as it influences donors' behaviour and enhances the organisation's competitiveness in the case of fund raising (Bennett \& Gabriel, 2003). An organisation with a good reputation is expected by the general public to behave positively which affects their willingness to contribute to charitable donations. In addition, the education sector has adopted the idea of corporate reputation with the assumption that reputable school will receive the same positive effects (Skallerud, 2011).

\section{Hypothesis}

H1 : Reputation has a significant positive relationship with competitive advantage

$\mathrm{H} 2$ : Competitive advantage has a significant positive relationship with financial performance of infaq received

H3 : Competitive advantage mediates the relationship between reputation and financial performance of infaq received

Based on the discussion above, conceptual research model can be described as in Fig. 1 


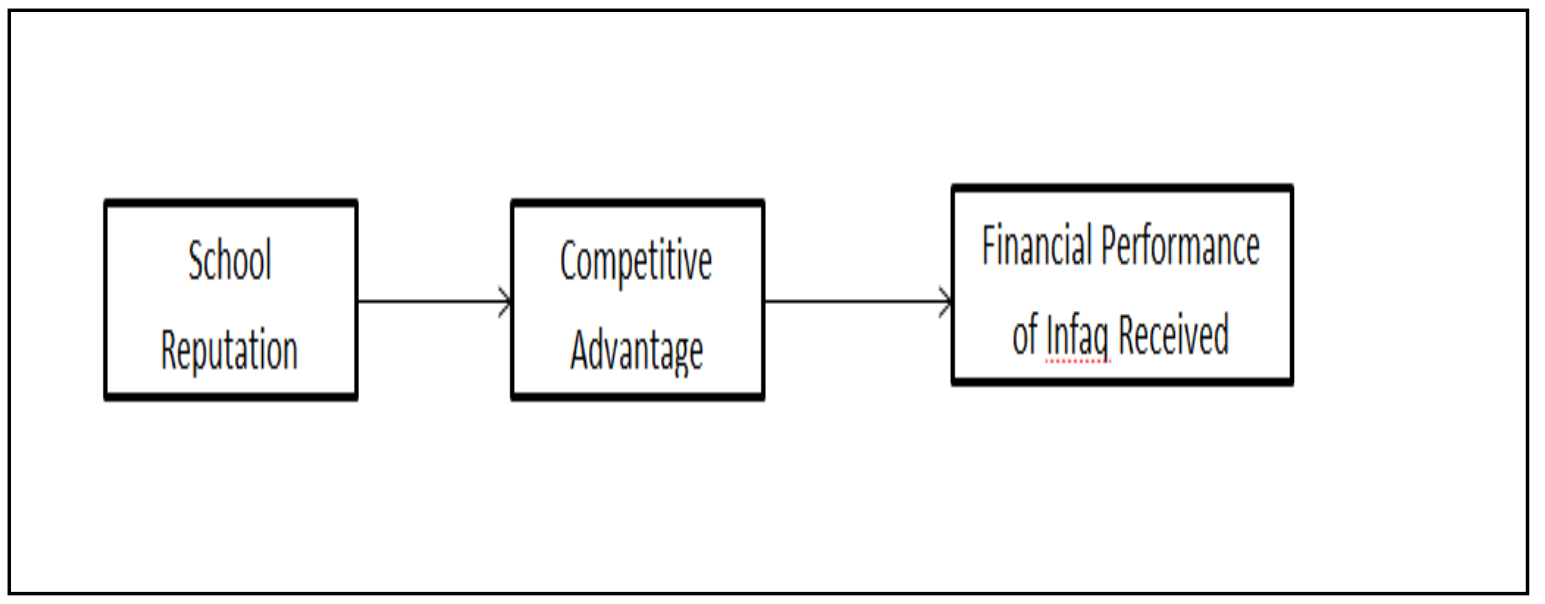

\section{Methodology}

\section{Population and Sample Size}

Presently, there are 1148 registered private Islamic schools listed by JAKIM. However, this study will only include private Islamic schools that have been established for more than five since new organizations need time to establish themselves with donors and achieve recognition. List of the schools is obtained from JAKIM's portal as well as from the list provided by State Islamic Religious Councils (SIRC). Due to incomplete data provided by JAKIM and SIRC regarding the year of establishment, this study's population only comprised 345 schools. The complete number of private Islamic schools in Malaysia according to the numerous categories of schools is shown in Table 1.

Table 1: Distribution of Population According to School Categories for 2019

\begin{tabular}{|l|c|c|c|c|c|}
\hline \multicolumn{1}{|c|}{ States } & $\begin{array}{c}\text { Pondok/ } \\
\text { Madrasah }\end{array}$ & Tahfiz School & $\begin{array}{c}\text { Islamic } \\
\text { Primary }\end{array}$ & $\begin{array}{c}\text { Islamic } \\
\text { Secondary }\end{array}$ & Total \\
\hline Kelantan & 15 & 19 & 11 & 2 & 47 \\
\hline Terengganu & 2 & 1 & 0 & 1 & 4 \\
\hline Pahang & 1 & 2 & 4 & 1 & 8 \\
\hline Perlis & 1 & 3 & 0 & 0 & 4 \\
\hline Pulau Pinang & 3 & 9 & 2 & 1 & 15 \\
\hline Kedah & 18 & 34 & 6 & 4 & 62 \\
\hline Perak & 5 & 20 & 4 & 2 & 31 \\
\hline Selangor & 5 & 63 & 31 & 4 & 103 \\
\hline Melaka & 6 & 7 & 0 & 3 & 16 \\
\hline Neg Sembilan & 0 & 11 & 3 & 1 & 15 \\
\hline Johor & 5 & 19 & 6 & 5 & 35 \\
\hline Sabah & 0 & 0 & 0 & 0 & 0 \\
\hline Sarawak & 0 & 0 & 2 & 0 & 2 \\
\hline Wilayah Persekutuan & 0 & 1 & 1 & 1 & 3 \\
\hline & & & & & 25 \\
\hline
\end{tabular}

Sources: Department of Islamic Development Malaysia (JAKIM) and State Religious Councils

\section{Data Collection Method}

A total of 200 questionnaires were distributed to the respective private Islamic schools. In order to enhance the response rate and gather personal experience and observation, the questionnaires were delivered by the researcher and enumerators appointed by the researcher through personal visit. 
INTERNATIONAL JOURNAL OF ACADEMIC RESEARCH IN BUSINESS AND SOCIAL SCIENCES Vol. 10, No. 9, 2020, E-ISSN: 2222-6990 @ 2020 HRMARS

Phone calls were made before visiting the respective schools for seeking their permission and setting an appointment. Besides that, some questionnaires were also emailed to schools that have not been covered by personal visits. The schools were asked to complete the self-administered questionnaire in Google form and return the answer online.

\section{Data Analysis}

This study used two statistical analysis techniques, which are the Statistic Package for Social Science (SPSS) and SmartPLS (PLS-SEM) version 3.2.9. SPSS were employed to analyse the sample's basic statistics. Meanwhile, the confirmatory factor analysis and hypothesis testing were performed using SmartLPS.

\section{Results of Findings and Discussion Response Rate}

A total of 200 questionnaires were distributed to the respective private Islamic schools. Out of 200 questionnaires, 148 were completed and returned, which is equivalent to a response rate of $74 \%$. However, two questionnaires were excluded because the respondents provided similar responses (straight lining) to all questions in the survey, resulting in 146 usable completed surveys (73\% usable response rate).

Table 2: Response rate

\begin{tabular}{lcccc}
\hline $\begin{array}{c}\text { School } \\
\text { Category }\end{array}$ & $\begin{array}{c}\text { Number of } \\
\text { Schools }\end{array}$ & $\begin{array}{c}\text { Questionnaires } \\
\text { Distributed }\end{array}$ & $\begin{array}{c}\text { Response } \\
\text { Received }\end{array}$ & Valid \\
\hline Primary School & 70 & 40 & 31 & 31 \\
Secondary School & 25 & 14 & 9 & 9 \\
Tahfiz School & 189 & 110 & 85 & 83 \\
Pondok/Madrasah & 61 & 36 & 23 & 23 \\
\hline Total & $\mathbf{3 4 5}$ & $\mathbf{2 0 0}$ & $\mathbf{1 4 8}$ & $\mathbf{1 4 6}$ \\
\hline
\end{tabular}

\section{Descriptive Analysis}

Table 3 present the school background. Based on the table, the highest number of respondents was from Tahfiz schools, followed by primary schools, Pondok/ Madrasah and secondary schools. Majority of the schools were located in the Northern Region, however Selangor recorded the highest number of respondents. A majority of private Islamic schools involved in this study have contributed towards education service operations for between 5-10 years while 4 schools were established more than 50 years ago. In terms of the number of employees, most schools reported that they have between 220 employees. Majority of schools involved in this study had more than 100 students with the largest number of students recorded at 1,248. In terms of the fees charged to students, $4.8 \%$ of schools did not charge any fee or have no fixed charges. This means that students pay their fees based on their parent's affordability. Majority of the schools charge tuition fees from RM 151 - RM 250 per month. 
INTERNATIONAL JOURNAL OF ACADEMIC RESEARCH IN BUSINESS AND SOCIAL SCIENCES Vol. 10, No. 9, 2020, E-ISSN: 2222-6990 @ 2020 HRMARS

Table 3: School background information

\begin{tabular}{|c|c|c|c|}
\hline Background & Information & Frequency & $\begin{array}{c}\text { Percentage } \\
(\%)\end{array}$ \\
\hline \multirow[t]{11}{*}{ Location } & Kedah & 23 & 15.8 \\
\hline & Kelantan & 20 & 13.7 \\
\hline & Selangor & 32 & 21.9 \\
\hline & Johor & 18 & 12.3 \\
\hline & Perak & 19 & 13.0 \\
\hline & Terengganu & 1 & 0.7 \\
\hline & Negeri Sembilan & 10 & 6.8 \\
\hline & Pulau Pinang & 10 & 6.8 \\
\hline & Pahang & 6 & 4.1 \\
\hline & Melaka & 5 & 3.4 \\
\hline & Perlis & 2 & 1.4 \\
\hline \multirow[t]{4}{*}{ Category } & Primary School & 31 & 21.2 \\
\hline & Secondary School & 9 & 6.2 \\
\hline & Tahfiz School & 83 & 56.8 \\
\hline & Pondok/Madrasah & 23 & 15.8 \\
\hline \multirow[t]{6}{*}{ Years of Establishment } & $5-10$ years & 58 & 39.7 \\
\hline & $11-20$ years & 48 & 32.9 \\
\hline & $21-30$ years & 29 & 19.9 \\
\hline & $31-40$ years & 6 & 4.1 \\
\hline & $41-50$ years & 1 & 0.7 \\
\hline & More than 50 years & 4 & 2.7 \\
\hline \multirow[t]{6}{*}{ Number of Staff } & Less than 10 person & 67 & 46.0 \\
\hline & $10-20$ person & 31 & 21.2 \\
\hline & 21-30 person & 16 & 11.0 \\
\hline & $31-40$ person & 17 & 11.6 \\
\hline & $41-50$ person & 4 & 2.7 \\
\hline & More than 50 person & 11 & 7.5 \\
\hline \multirow[t]{5}{*}{ Number of Students } & Less than 25 students & 16 & 11.0 \\
\hline & $26-50$ students & 25 & 17.1 \\
\hline & $51-75$ students & 25 & 17.1 \\
\hline & $76-100$ students & 12 & 8.2 \\
\hline & More than 100 students & 68 & 46.6 \\
\hline \multirow[t]{6}{*}{ Fees } & Free/ No Fixed Amount & 7 & 4.8 \\
\hline & Below RM 150 & 26 & 17.8 \\
\hline & RM 151-RM 250 & 47 & 32.2 \\
\hline & RM 251-RM 350 & 34 & 23.3 \\
\hline & RM 351-RM 450 & 15 & 10.3 \\
\hline & More than RM 450 & 17 & 11.6 \\
\hline
\end{tabular}

\section{Measurement of Reliability and Validity}

The Composite Reliability (CR) coefficient was used to access the internal consistency and stability of the measurement items (Chin, 2010; Hair et al., 2011). In addition, Hazen et al., (2015) suggested that in order to provide evidence of reliability, two measures are routinely used, such as Cronbach's Alpha for item or indicator reliability and CR for internal consistency reliability. Therefore, these two sets of reliability measurement models were used. In addition, to evaluate convergent validity of reflective constructs, studies consider the outer loadings of the indicators and the average variance extracted (AVE) (Hair et.al, 2017). A common rule of thumb is that the standardized outer loadings should be 0.708 or higher (Hair et al., 2017). However, according to Hair et al. (2014), items with moderate loadings between 0.5 to 0.7 can be retained as long as the Average Variance Extracted 
INTERNATIONAL JOURNAL OF ACADEMIC RESEARCH IN BUSINESS AND SOCIAL SCIENCES Vol. 10, No. 9, 2020, E-ISSN: 2222-6990 @ 2020 HRMARS

(AVE) for latent variables is above 0.5. In order to retain an AVE of above 0.50, some items with weaker outer loadings (below 0.708 ) were removed. Table 4 shows the results for measurement of reliability and convergent validity.

Table 4: Results of measurement reliability and convergent validity

\begin{tabular}{ccccc}
\hline Construct & $\begin{array}{c}\text { Loading } \\
\text { Range }\end{array}$ & $\begin{array}{c}\text { Composite } \\
\text { Reliability (CR) }\end{array}$ & $\begin{array}{c}\text { Cronbach's } \\
\text { Alpha }\end{array}$ & AVE \\
\hline FP & $0.911-0.951$ & 0.95 & 0.924 & 0.865 \\
CA & $0.708-0.849$ & 0.835 & 0.704 & 0.63 \\
IC & $0.733-0.847$ & 0.892 & 0.848 & 0.624 \\
SN & $0.804-0.850$ & 0.894 & 0.841 & 0.677 \\
SC & $0.708-0.804$ & 0.855 & 0.774 & 0.596 \\
LS & $0.743-0.864$ & 0.94 & 0.927 & 0.662 \\
WC & $0.768-0.832$ & 0.871 & 0.803 & 0.629 \\
CS & $0.759-0.926$ & 0.917 & 0.877 & 0.734 \\
IO & $0.804-0.852$ & 0.919 & 0.89 & 0.694 \\
\hline
\end{tabular}

Note: FP=Financial Performance; CA=Competitive Advantage; IC=Intellectual Capital; $S N=S c h o o l$ Networking; SC=Student Competency; $L S=L$ Ladership; WC=Workplace Climate; $C S=$ Citizenship; $10=$ Innovation

\section{Discriminant Validity}

Discriminant validity determines which construct is truly distinct from other constructs by empirical standards. The cross-loadings, Fornell-Larcker criterion, especially the heterotrait-monotrait (HTMT) ratio of correlations, can be used to examine discriminant validity. This study only used the HTMT approach for discriminant validity. As shown in Table 5, the HTMT for all constructs is below 0.90, which demonstrates adequate discriminant validity.

Table 5: The HTMT Results

\begin{tabular}{|c|c|c|c|c|c|c|c|c|c|c|}
\hline & Citizenship & $\begin{array}{l}\text { Competitive } \\
\text { Advantage }\end{array}$ & $\begin{array}{l}\text { Financial } \\
\text { Performance }\end{array}$ & Innovation & $\begin{array}{l}\text { Intellectual } \\
\text { Capital }\end{array}$ & Leadership & Reputation & $\begin{array}{l}\text { School } \\
\text { Networking }\end{array}$ & $\begin{array}{l}\text { Student } \\
\text { Competency }\end{array}$ & $\begin{array}{l}\text { Workplace } \\
\text { Climate }\end{array}$ \\
\hline \multicolumn{11}{|l|}{ Citizenship } \\
\hline Competitive Advantage & 0.216 & & & & & & & & & \\
\hline Financial Performance & 0.077 & 0.052 & & & & & & & & \\
\hline Innovation & 0.587 & 0.398 & 0.072 & & & & & & & \\
\hline Intellectual Capital & 0.478 & 0.417 & 0.112 & 0.518 & & & & & & \\
\hline Leadership & 0.592 & 0.513 & 0.114 & 0.603 & 0.604 & & & & & \\
\hline Reputation & 0.771 & 0.54 & 0.129 & 0.818 & 0.845 & 0.9 & & & & \\
\hline School Networking & 0.511 & 0.368 & 0.171 & 0.374 & 0.588 & 0.553 & 0.746 & & & \\
\hline Student Competency & 0.42 & 0.638 & 0.079 & 0.617 & 0.738 & 0.64 & 0.853 & 0.54 & & \\
\hline Workplace Climate & 0.589 & 0.43 & 0.089 & 0.691 & 0.658 & 0.671 & 0.885 & 0.526 & 0.652 & \\
\hline
\end{tabular}

\section{Hypothesis Testing}

For this, the path analysis was used to test hypotheses generated from the research model. The $\mathrm{R}^{2}$ for dependent variable (financial performance of infaq) is 0.031 , meaning that only $3.1 \%$ of the variance can be explained by reputation. This result is considered as weak. The $\mathrm{R}^{2}$ for competitive advantage $(0.216)$ can be considered as moderate. This indicates that $21.6 \%$ of the variance in competitive advantage could be explained by reputation. Next, the $\mathrm{f}^{2}$ is a complementary test for $\mathrm{R}^{2}$, 
INTERNATIONAL JOURNAL OF ACADEMIC RESEARCH IN BUSINESS AND SOCIAL SCIENCES Vol. 10, No. 9, 2020, E-ISSN: 2222-6990 @ 2020 HRMARS

where changes to $R^{2}$ are observed with the omission of any selected exogenous variable from the model. Results of $f^{2}$ values for all combinations of endogenous constructs and corresponding exogenous constructs show that reputation has a medium effect on competitive advantage (0.14). On the other hand, competitive advantage was found to have no effect on financial performance (0.00). The effect of competitive advantage on financial performance is not significant (b path: $\beta=0.05$. $t=0.023, p=0.491)$. Hence, it can be concluded that competitive advantage does not mediate reputation with financial performance

Table 6: Hypothesis testing

\begin{tabular}{cll|c|c|c|c|c}
\hline Hypothesis & \multicolumn{1}{c}{ Relationship } & \multicolumn{2}{c}{ Beta } & \multicolumn{2}{c}{ Std Error T- Value P Values } & $\mathrm{f}^{2}$ & Decision \\
\hline H1 & Reputation -> Competitive Advantage & 0.382 & 0.098 & $3.834^{* *}$ & 0.000 & 0.141 & Supported \\
\hline H2 & Competitive Advantage -> Financial Performance & 0.005 & 0.092 & 0.023 & 0.491 & 0.000 & Not supported \\
\hline
\end{tabular}

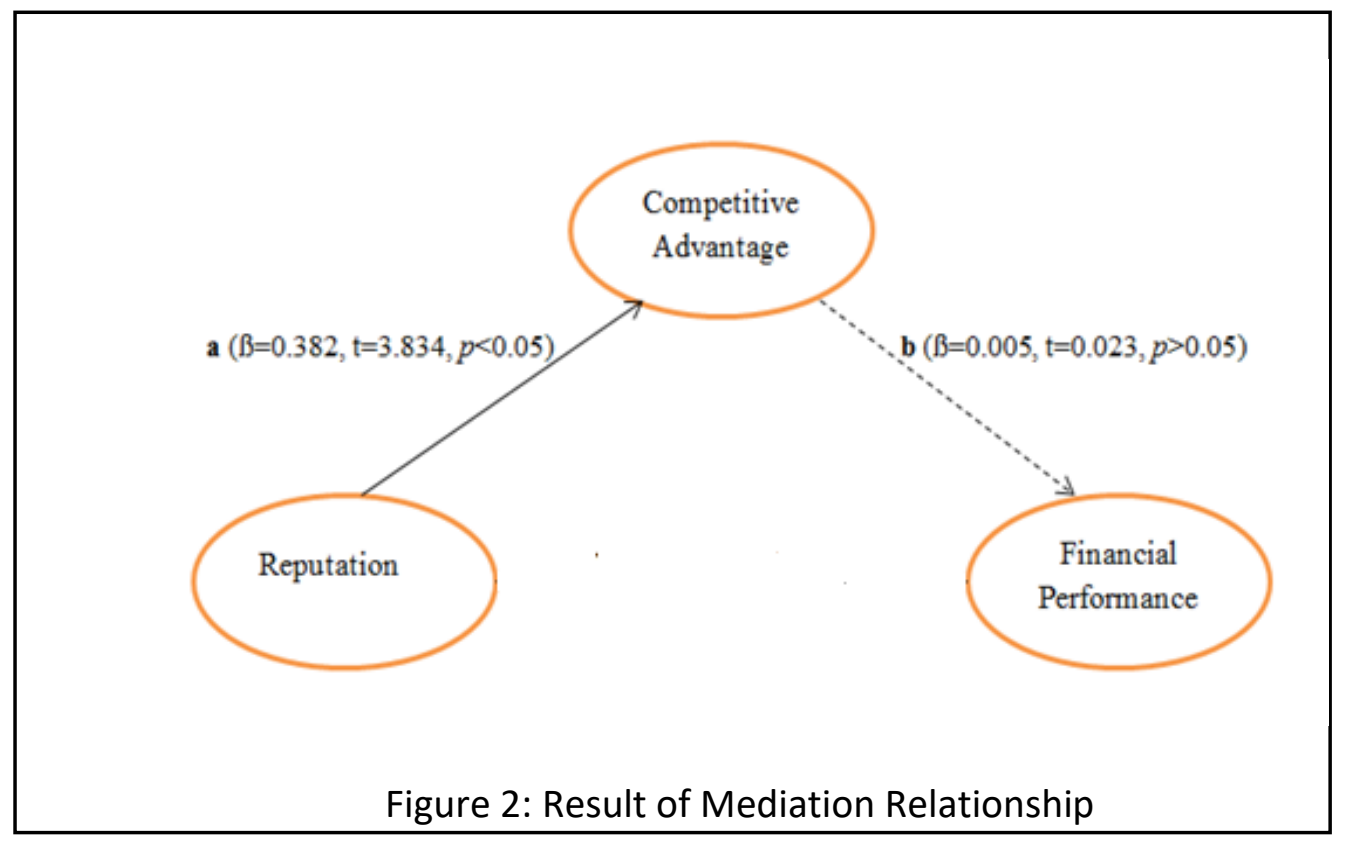

\section{Discussion and Conclusion}

Findings of this study reveal a significant relationship between reputation and competitive advantage of private Islamic schools in Malaysia. Since the result indicate that reputation is significantly and positively related to competitive advantage, the propositions of this study confirm that reputation is the one of the most important internal resources that an organisation should consider in order to gain competitive advantage. The vast number of private Islamic schools in Malaysia makes it difficult for donors to decide which school they should donate to. In order to compete for the pool of financial resources, private Islamic schools should possess their own uniqueness and competitive advantage. A good reputation is a key driver for long-term competitive advantage and ensures long-term financial funding to non-profit organisations (Roberts \& Dowling, 2002; Sarstedt \& Schloderer, 2010; Tuckman, 1998).

However, this study found that competitive advantage is insignificantly related to the financial performance of infaq, which means that competitive advantage does not influence the financial 
INTERNATIONAL JOURNAL OF ACADEMIC RESEARCH IN BUSINESS AND SOCIAL SCIENCES Vol. 10, No. 9, 2020, E-ISSN: 2222-6990 @ 2020 HRMARS

performance of infaq received by private Islamic schools in Malaysia. Hence, competitive advantage does not mediate the relationship between repitation and financial performance of infaq received. Although some private Islamic schools can sustain competitive advantage over other schools, other factors should be considered when explaining why this competitive advantage does not lead to a better financial performance by infaq. Among the factors that should be considered are school location, effective communication, the role of Parent-Teacher Association and the amount of fees charge on each student.

\section{Acknowledgement}

The research study is financed by Ministry of Higher Education Malaysia as well as University Malaysia Kelantan under SLAB program. The researcher also wishes to thank Dr Kati Suomi from University of Turku, Finland for sharing information regarding this subject. This acknowledgement also goes to Ustaz Abdul Rashid b Abdul Lateh, the Principal of SRI Aman Wakaf Bharu, Ustaz Ahmad Shairazi b Hj Atiqullah, the General Secretary of Pusat Pembangunan Pondok Berhad, Ustaz Usman b Alias, the Director of Pusat Pendidikan Aman, Ustaz Nik Omar b Nik Abdul Aziz, the Chairman of YADIM, Nik Mohd Azam Nik Wajis and all principals, chairmans, teachers and all the respondents and interviewees of pondok, tahfiz, SRI and SMI for their support and willingness to devote their precious time and effort to be a part of this study as well as their cooperation, valuable information and assistance in the data collection. Not to forget, to all enumerators who offered their time and effort in helping me completing the survey.

\section{Corresponding Author}

Sofri b Yahya, Graduate School of Business, Universiti Sains Malaysia, Email: sofri@usm.my

\section{References}

Agyemang, O. S., \& Ansong, A. (2017). Corporate social responsibility and firm performance of Ghanaian SMEs. Journal of Global Responsibility, 8(1), 47-62. https://doi.org/10.1108/JGR-032016-0007

Ambotang, A. S., \& Majuleka, N. A. (2018). Peranan Sekolah Agama Rakyat dalam pembentukan modal insan. Utusan Borneo.

Andres, L. (2017). History repeats itself because we fail to learn from the past. New Straits Times.

Aziz, M. A. F. A. (2018). Kuantan tahfiz worker to be charged with sexual abuse of 10 boys. New Straits Times.

Barney, J. (1991). Firm Resources and Sustained Competitive Advantage. Journal of Management, 17(1), 99-120. https://doi.org/10.1177/014920639101700108

Bennett, R., \& Gabriel, H. (2003). Image and Reputational Characteristics of UK Charitable Organizations: An Empirical Study. Corporate Reputation Review, 6(3), 276-289. https://doi.org/10.1057/palgrave.crr.1540206

Bernama. (2018). Two teachers detained for allegedly threatening to cut off boy's private part. New Straits Times.

Carmeli, A., \& Tishler, A. (2005). Perceived organizational reputation and organizational performance: An empirical investigation of industrial enterprises. Corporate Reputation Review, 8(1), 13-30.

Chin, W. W. (2010). How to Write Up and Report PLS Analyses. In Handbook of Partial Least 
INTERNATIONAL JOURNAL OF ACADEMIC RESEARCH IN BUSINESS AND SOCIAL SCIENCES Vol. 10, No. 9, 2020, E-ISSN: 2222-6990 @ 2020 HRMARS

Squares. Springer Handbooks. https://doi.org/10.1007/978-3-540-32827-8

Hair, J. F., Ringle, C. M., \& Sarstedt, M. (2011). PLS-SEM : Indeed a Silver Bullet. 19(2), 139-151. https://doi.org/10.2753/MTP1069-6679190202

Hall, R. (1993). A Framework Linking Intangible Resources and Capabilities to Sustainable Competitive Advantage. Strategic Management Journal, 14, 607-618.

Hazen, B. T., Overstreet, R. E., \& Boone, C. A. (2015). Suggested reporting guidelines for structural equation modeling in supply chain management research. International Journal of Logistics Management, 26(3), 627-641. https://doi.org/10.1108/IJLM-08-2014-0133

Huang, S. L., \& Ku, H. H. (2016). Brand image management for nonprofit organizations: Exploring the relationships between websites, brand images and donations. Journal of Electronic Commerce Research, 17(1), 80-96.

Ibrahim, M. S., Aziz, S. A., \& Azman, N. (2005). Amalan Pengurusan Berasaskan Sekolah di Sekolahsekolah Swasta di Malaysia: Satu Tinjauan. In Jurnal Pendidikan. Institut Aminuddin Baki, KPM.

Ismail, S. (2016). Institusi Tahfiz di Malaysia : Prospek dan Cabaran. Simposium Antarabangsa Tahfiz.

Rindova, V. P., Williamson, I. O., Petkova, A. P., \& Sever, J. M. (2005). Being good or being known: An empirical examination of the dimensions, antecedents, and consequences of organizational reputation. Academy of Management Journal, 48(6), 1033-1049. https://doi.org/10.5465/AMJ.2005.19573108

Roberts, P. W., \& Dowling, G. R. (2002). Corporate reputation and sustained superior financial performance. Strategic Management Journal, 23(12), 1077-1093. https://doi.org/10.1002/smj.274

Sarstedt, M., \& Schloderer, M. P. (2010). Developing a measurement approach for reputation of non-profit organizations. International Journal of Nonprofit and Voluntary Sector Marketing, 15, 276-299. https://doi.org/10.1002/nvsm

Skallerud, K. (2011). School reputation and its relation to parents ' satisfaction and loyalty. International Journal of Education Management, 25(7), 671-686. https://doi.org/10.1108/09513541111172081

Suomi, K. (2015). Managing Brand Identity and Reputation - A Case Study from Finnish Higher Education. University of Turku.

Tuckman, H. P. (1998). Competition, Commercialization, and the Evolution of Nonprofit Organizational Structures. Journal of Policy Analysis and Management, 17(2), 175-194.

Ying, T. P. (2018, April 9). Four girls injured in Subang Jaya tahfiz school fire. New Straits Times. 